\title{
Determination of electrophoretic pattern of infectious bovine rhinotrachities virus of cattle
}

\author{
Hanan, A. Fahmy ${ }^{1}$, Omayma, M. El Desawy ${ }^{2 *}$ \\ ${ }^{1}$ Biotechnology Research Department, ${ }^{2}$ Virology Research Department, \\ Animal Health Research Institute, Dokki, Egypt
}

\begin{abstract}
A total number of 80 nasal swabs collected from apparently normal cattle slaughtered in Basateen abattoir were screened for the presence of infectious bovine rhinotracheitis virus. Among 80 examined samples, 4 samples found positive after the $3^{\text {rd }}$ passage on MDBK cell line with appearance of the specific cytopathic effect (grape like clusters). The isolated virus titers were $10^{3.9}, 10^{4.2}, 10^{5}, 10^{5.6}$ TCID50 / $0.1 \mathrm{ml}$. The four positive isolates were identified by agar gel precipitation test (AGPT), virus neutralization test (VNT) and gave the intracytoplasmic granules by indirect fluorescent antibody technique (IFAT). Electrophoretic profile of IBR in sodium dodecyl sulfate polyacrylamide gel electrophoresis (SDS-PAGE) was described and visualized by Coomassie blue stain. The mobilities of electrophoretic bands were determined with molecular weight marker at approximate range from 206.39 to $22.14 \mathrm{kDa}$.
\end{abstract}

Infectious bovine rhinotracheitis (IBR) is a highly infectious viral disease, which was early recognized in USA, and it is distributed worldwide paralleling the distribution of domestic cattle. It is one of the most important diseases of domestic and wild cattle that cause huge economic losses (Ackermann et al., 1990 and OIE, 2004).

The disease is caused by a virus belonging to Family Herpesviridae. Herpesvirus consists of DNA protein core. The envelope contains a number of lipoproteins. The capsid is composed of at least four unique proteins and so-called tegument consists of about eight distinct polypeptides (Dulbecco and Ginsberg, 1980). All IBR strains were similar to each other in polypeptides composition of the virus by using polyacrylamide gel electrophoresis (PAGE) (Pastoret et al., 1980).

Bovine herpes-virus 1 (BHV-1) is an important pathogen of cattle (Inman et al., 2001). BHV-1 is the cause of IBR and infectious pustular vulvovaginitis (IPV) in cattle, establishes a life long infection, despite the presence of antiviral immunity in the host (Lalic et al., 2003). The disease is characterized by conjunctivitis, mucopurulent nasal discharge,

* Corresponding author. Tel.: +2023599422; fax: +2025716840 .

E-mail address: omyma.eldesawy@yahoo.com (Omayma, M. El Desawy). fever, depression, abortion, vulvovaginitis and balanoposthitis. Secondary bacterial infection results in fatal pneumonia (Winkler et al., 1999).

In Egypt the virus was isolated from cattle showing abortion (Madbouly and Hussein 1997) and also from slaughtered cattle in Cairo and Giza abattoirs (Ibrahim, 1998).

In the present article, we try to isolate IBR virus from nasal swabs collected from apparently normal cattle slaughtered in Basateen abattoir, Cairo, Egypt on MDBK cell line. The virus was identified by AGPT, VNT and IFAT using reference anti sera. Determination of electrophoretic pattern of the isolated IBR virus by SDS-PAGE and comparing its molecular weight with known mol w marker was also studied.

\section{Material and Methods}

Samples. A total of 80 nasal swabs were collected from apparently normal cattle slaughtered in Basateen abattoir. Each swab was immersed in sterial tube containing minimal essential medium (MEM).

Antisera. Reference positive antisera supplied by Fac. Vet. Med. Cairo Univ. It used for identification of isolated IBR by VNT, AGPT and IFAT.

Virus isolation. Madin Darby bovine kidney (MDBK) cells were grown in (MEM) supplemented with $10 \%$ fetal calf serum. Each 
Table (1): Number of nasal swabs sample showing CPE.

\begin{tabular}{cccccc}
\hline Total samples & $\begin{array}{c}\text { No of +ve samples } \\
\text { in TC }\end{array}$ & $\begin{array}{c}\text { \% of +ve } \\
\text { samples }\end{array}$ & & \multicolumn{2}{c}{ Appearance of C.P.E in T.C } \\
\cline { 3 - 5 } & 4 & $5 \%$ & & ++ & 2 sample \\
\hline \multirow{2}{*}{80} & 4 & & & ++ \\
\hline
\end{tabular}

suspected material was inoculated into MDBK cells in $10 \%$ suspension and incubated at $37^{\circ} \mathrm{C}$, $5 \% \mathrm{CO} 2$ for 4 days. Each suspected material was subjected to three passages. Isolates showed no cytopathic effect (CPE) after the $3^{\text {rd }}$ passage were considered negative.

Identification of isolated IBR virus.

Virus neutralization test. It was done according to (Brian and Hiller, 1996). A serial ten fold dilution of standard positive antiserum mixed with ten-fold dilution of isolated virus in each well in microtiter plate, incubate at $37^{\circ} \mathrm{C}$ for $1 \mathrm{~h}$, then MDBK cells were added. The plate was incubated for 4 days at $37^{\circ} \mathrm{C}$ and examined daily for the presence of CPE. The titer was calculated according to (Reed and Muench, 1938).

Indirect fluresent antibody technique (IFAT). It carried out according to (Majewska et al., 1984) $0.2 \mathrm{ml}$ of suspected isolate after $3^{\text {rd }}$ passage was added on MDBK cell line grown on cover slips. After showing $50 \%$ of CPE $(24 \mathrm{~h})$, cells were fixed with acetone for $15 \mathrm{~min}$. Reference BHV1 antiserum was added and incubated for $30 \mathrm{~min}$. then unbound antibodies were washed out Antibovine immunoglobulin conjugated with fluorescein isothiocyanate stain was added for 30 min. The cover slip was washed, covered with mounting buffer and examined using fluorescent microscope.

Agar gel precipitation test: It was done according to (Payment and Trudel, 1993).

SDS-polyacrylamide gel electrophresis:- The electrophoresis of IBR was determined according to (Laemmli, 1970). Briefly, infected MDBK cells were collected when cytopathic effect become evident. Monolayers culture flasks were freezed and thwing three times. The suspension was clarified at low speed centrifugation at $2000 \mathrm{rpm}$ for $10 \mathrm{~min}$. at $4^{\circ} \mathrm{C}$. IBR virus was concentrated by polyethyleneglycol, and heated at $100^{\circ} \mathrm{C}$ for 6 min. in SDS - 2 mercapto ethanol loading buffer. The proteins were separated on resolving polyacrylamide gel $(10 \%)$ using a vertical discontinuous gel system (BIO-RAD, Miniprotein cell with cat. No. 40221 USA) with stacking gel
$(5 \%)$ in SDS $(0.1 \%)$ in glycin running buffer at constant volt (100) for $2 \mathrm{~h}$. The molecular size of protein have been determined by comparing their electrophoretic nobilities with those of known standard mol. w marker after staining by Coomassie blue stain.

\section{Results and Discussion}

IBR is caused by a virus which has been classified among members of Family Herpesviridae, Subfamily Alphaherpesvirinae and now commonly referred as bovine herpesvirus type -1 (BHV -1). The virus produces latent infection and persists in closed herds, under stress condition. The latent virus can be reactivated resulting in recurrent clinical disease (Boden, 1991).

BHV-1 infections occur world wide and cause serious economic losses due to deaths of animals, abortion, decreased milk productions and loss of body weight. BHV is frequently found in bovine semen and is transmitted through natural service and artificial insemination (Joseph et al., 2002). Trail for isolation of IBR virus on MDBK cells were examined daily for the presence of CPE. After 3rd passage 4 samples out of 80 nasal swabs produced the CPE including rounding, shrinkage and aggregation of cells in the form of grape like cluster appearance (48h post inoculation ) (Table 1, Fig. 1, 2).

Results of virus isolation attempts from nasal swabs on MDBK cell line agreed with Faye et al., (1976) who reported that MDBK is stable than the primary cell culture BK, and also the use of BK that may be contaminated with bovine viral diarrhea. The CPE in the 4 positive samples showed the formation of grape like appearance (Fig. 1,2), is in agreement with Ibrahim et al., (1983), and Shehab et al., (1996) who isolated IBRV from nasal swabs and found similar CPE. By identification with virus neutralization test, differences in the titer of virus isolates $\left(10^{3.9}\right.$, $\left.10^{4.2}, 105,10^{5.6} \mathrm{TCID}_{50} / 0.1 \mathrm{ml}\right)$ were observed. The 4 positive isolates gave positive line of precipitation in AGPT upon using reference BHV-1 serum (data not shown ). This result 


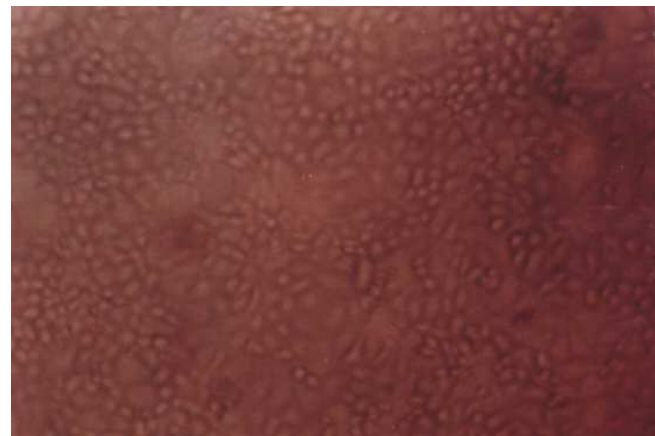

Fig(1): Control non infected MDBK cells (40X).

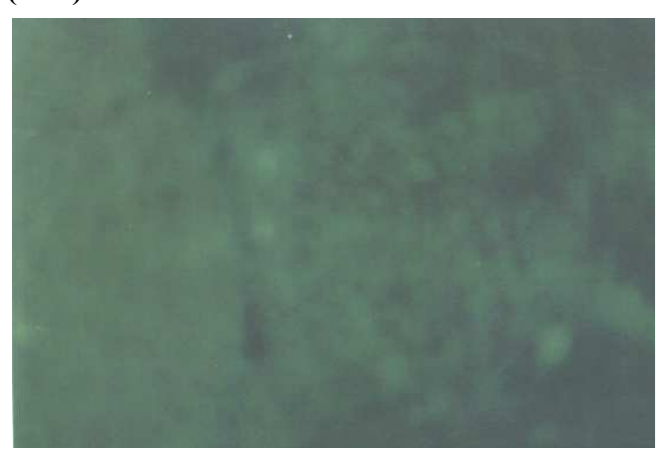

Fig(3): Control non infected MDBK cells stained by fluorescence isothiocyanate (40X).

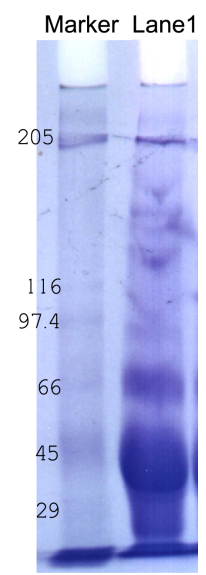

Fig (5): Electrophoretic pattern of infectious bovine rhinotracheitis (IBR) virus in SDS - PAGE with Coomassie blue stain with resolution ranged from 206.39 to $17.143 \mathrm{kDa}$. Lane (1): protein marker, Lane (2): IBR virus.

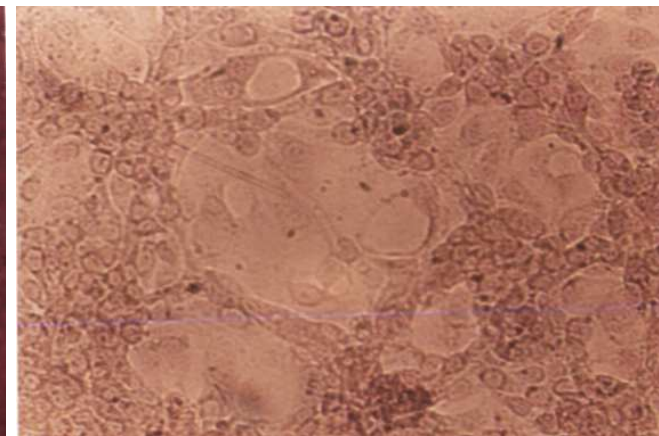

Fig(2): Cytopathic effect Of IBR virus isolated on MDBK 48 hours post inoculation (40X).

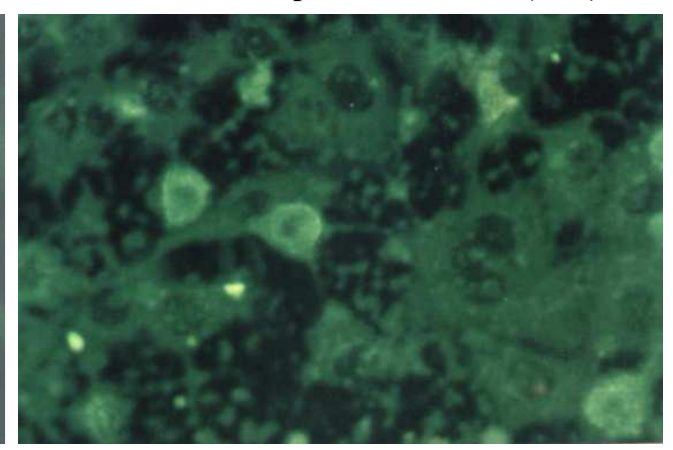

Fig(4): MDBK cells infected IBR isolate stained by fluorescence with specific preinuclear yellowish green fluorescent granules (40X).

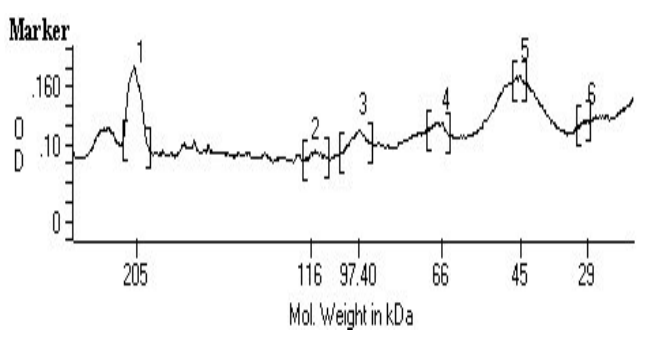

Fig. (6): Molecular weight curve of the marker proteins using SDS - PAGE.

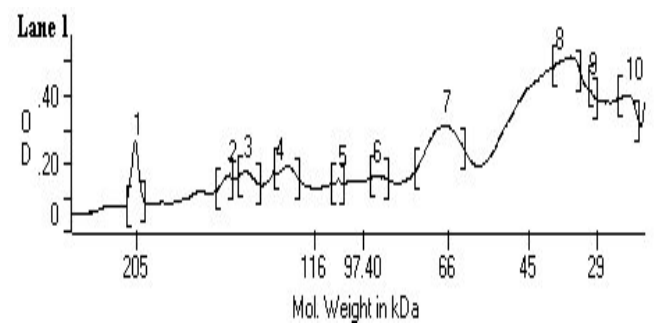

Fig. (7): Molecular weight curve of IBR virus proteins using SDS - PAGE 
Table (2): Estimation of the molecular weight of IBR virus compared.

\begin{tabular}{ccc}
\hline Lanes: & Marker & Lane 1 \\
\hline Rows & (mol.w.) & (mol.w.) \\
\hline r1 & 205 & 206.39 \\
r2 & & 158.76 \\
r3 & & 140.11 \\
r4 & & 125.47 \\
r5 & 116 & \\
r6 & & 108.97 \\
r7 & 97.4 & 97.026 \\
r8 & 66 & 69.817 \\
r9 & 45 & \\
r10 & & 42.796 \\
r11 & 29 & 30.796 \\
r12 & & 17.143 \\
\hline
\end{tabular}

agreed with Straub, (1986) who reported that immuno - diffusion test is suitable for laboratory diagnosis of IBR virus. The indirect fluorescent antibody technique was also used to identify the positive isolates due to its higher sensitivity than direct fluorescent antibody technique (Majewska et al., 1984). The isolated viruses were tested by IFAT (Fig.3,4). Viral antigens were observed in the cytoplasm. This may be due to the rapid escaping of virus particles from the nucleus to the cytoplasm. Similar finding was reported by Mohnty and Dutta, (1981) who found only cytoplasmic fluorescence and unable to find intranuclear fluorescence.

Concerning SDS-PAGE analysis of IBR virus Mol $\mathrm{w}$ is given in $\mathrm{kDa}$ ranged from 206.39 to $22.14 \mathrm{kDa}$ as shown in (Table 2, Fig. 5). Mohanty and Dutte, (1981) described that virion capsid of IBR was $120-150 \mathrm{~nm}$ in diameter surrounded by a lipid- containing envelop. There were 33 proteins in virion with molecular weight of 80-110 X10 . Our present results agree with that obtained by Hughes et.al., (1988) who purified BHV-1 glycoprotein GIV by affinity chromatography and showed two distinct components of 71 and 140 $\mathrm{kDa}$ following electrophoresis in SDS-PAGE. Similar observation were obtained when three new proteins with approximate molecular weights 125,42 and $17 \mathrm{kDa}$ were identified by Seal, (1988) in chromatin isolated from BHV -1 infected bovine embryonic lung (BEL) cell at ten hours post infection. They also recognized the 17 $\mathrm{kDa}$ mol $\mathrm{w}$ protein by BHV -1 virion specific antisera. A panel of murine monoclonal antibodies (MAbs) to BHV-1 was prepared by Abdel
Magid et al., (1992). Three of them were neutralizing MAbs and reacted against 130, 75, 50 $\mathrm{kDa}, 77 \mathrm{kDa}$ glycoproteins (gp). A fourth non neutralizing MAB recognized the $97 \mathrm{kDa}$. gp. The later one was similar with our investigation.

Serum neutralizing activities were analyzed by reaction with crude antigen extract in immunoprecipitation SDS-PAGE and western blot (Lun and Reed, 1986). Four virus- specified glycopeptides, with mol w of $69-75,77-81,82-92$ and $108-115 \mathrm{kDa}$, appeared to be involved in inducing serum neutralizing antibody. These results are in agreement with the present data (Table 2).

Ludwing (1983) detected two common glycoproteins; 74 and $91 \mathrm{kDa}$ which are responsible for the cross neutralization between BHV -1 and caprine herpesvirus whereas Misre et. al., (1982) detected a glycoprotein (GP -1) with mol w $71.5 \mathrm{kDa}$ induced by BHV -1 on the external surface of infected cells. They categorized it as an early protein or B class protein since it was synthesized early in infection processes. Chung and Hsu, (1996) determined BHV-1 gene product which has nuclease activity and produced a $57 \mathrm{kDa}$ protein. Desloges and Simard, (2001) characterized the expression kinetics of transcript generated from BHV -1 homologue of herpes simplex virus-1, UL 12. UL 12 specific antiserum generated against a T7- Tag /UL 12 fusion protein expressed in $E$ coli detected a $53 \mathrm{kDa}$ protein in cell lysates from BHV-1 infected cell, whose size correlated with that predicted $(51.844 \mathrm{kDa})$ which accumulated from 12-30 $\mathrm{h}$ post infection.

In conclusion IBR is one of the most important diseases of cattle which need careful diagnosis as the clinical disease of respiratory tract is often caused by several factors acting together. Therefore vaccination, sanitary precaution and control measures during movement of animals as well as animal production by artificial insemination are essential measures of IBR control.

\section{References}

Abdel Magid, O. Y.; Orten, D. J.; Xue, W.; Blecha, F. and Minocha, H. C. (1992): Anti-idiotypic antibodies to bovine herpesvirus-1 inhibit virus infection in cell cultures. Arch. Virol., 122 (1-2): 163 - 173.

Ackermann, M. ; Muller, H. K.; Bruckner, L. ; Riggenbach, C. and Kim, U. (1990): Eradication of infectious bovine rhinotracheitis in Switzerland. Vet. Microbiol., 23: 365 - 370.

Boden, E. (1991): Sheep and goat practice : A text book of disease of sheep and goats. $1^{\text {st }}$ ed. Bailiere Tindall. London. 
Brain, W. J. and Hiller, O. K. (1996): Virology Methods Manual. Acad. Press, New York, USA. pp. $108-110$.

Chung, Y. T. and Hsu, W. (1996): Functional expression of the bovine herpes virus 1 alkaline deoxyribonuclease (UL12) in Escherichia coli. Arch. Virol., 141 (12): 24572464.

Desloges, N. and Simard, C. (2001): Expression Kinetics of the later UL 12 gene encoding the bovine herpes virus 1 alkaline nuclease. Arch. Virol., 146 (10): 1871 - 1884.

Dulbecco, R.; and Ginsberg, S. H. (1980): In Virology, "Herpesviridae" Hagerstown, Cambridge comp. and Row Publishers pp.1062 - 1066.

Faye, P.; Charton, A.; Layec, C. and Solsona, M. (1976): Simple neutralization technique for bovine rhinotracheitis virus. Recueit de Medicine Veterinaire, 152 (7-8): 483 489

Hughes, G.; Babiuk, L. A. and Hurk, V. D. (1988): Functional and topographical analyses of epitopes on bovine herpes virus type 1 glycoprotein 1V. Arch. Virol., 103 (1-2): $47-60$.

Ibrahim, S. M. (1998): Rapid detection of some respiratory viral disease in Bovine. MVSc., Thesis, Fac. Vet. Med., Cairo. Univ. Egypt.

Ibrahim, S. P.; Fatimah, I. and Saharee, A. A. (1983): Isolation of IBR virus from buffaloes in Malaysia. Vet. Rec., 112 (13): 303 - 304.

Inman, M.; Lovato, L.; Doster, A. and Jones, C. (2001) A Mutation in the latency - Related Gene of Bovine Herpesvirus 1 leads to impaired ocular shedding in acutely infected calves. J. Virol., 75 (18): $8507-8515$.

Joseph, T.; Lyaku, J.; Fredrickson, R. A.; Cepica, A. and Kibenge, F. S. B. (2002): Use of Epitope Mapping to identify a PCR Template for protein Amplification and Detection by Enzyme - Linked immunosorbent Assay of Bovine Herpes virus Type 1 Olycoprotein D. J. Clin. Microbiol., 40 (11): 4045 - 4050.

Laemmli, U. K. (1970): Cleavage of structural proteins during assembly of the head of bacteriophage T 4 . Nature 227: $680-685$.

Lalic, D. K.; Rychlowski, M.; van Leeuwen, D.; Rijsewijk, F. A. M.; Ressing, M. E.; Neefjes, J. J.; Szewczyk, K. B. and Wiertz, E. J. (2003): Bovine herpes virus 1 interferes with TAP- dependent peptide transport and intracellular trafficking of MHC class molecules in human cells. Arch. Virol., 148 (10): 2023- 2037.

Ludwig, H. (1983): Bovine herpesviruses. In the herpesviruses. Vol. 2 Plenum press, New York. pp.135 214.
Lum, M. A. and Reed, D. E. (1986) : Identification of bovine herpes virus -1 polypeptides involved in serum neutralization. Vet. Microbiol., 11(3): $213-220$.

Madbuly, H. M. and Hussien, M. M. (1997): Isolation of BHV -1 from dairy herd showing genital form of infection. Alex. J. Vet. Sci., 13 (4): 439 - 446.

Majewska, H.; Zmudinski, J. and Baczynski, Z. (1984): The use of different immunofluorescent methods for identification of IBR / IPV and BVD - MD viruses. Bull. Vet. Inst. In pulway, 27 (1-4): $60-64$.

Misra, V.; Gilchrist, J. E.; Weinmaster, G.; Quatiene, I.; Hurk S. V. and Babiuk, L. A. (1982): Herpes virus induced early glycorprotein, characterization and possible role in immune cytolysis. J. Virol. 43 (3): 1046 - 1054.

Mohanty, S. B. and Dutta, S. K. (1981): Classification and nomenclature of animal viruses. In: Veterinary Virolology, pp. $107-116$.

OIE (2004): Manual of diagnostic tests and vaccines for terrestrial animals, $5^{\text {th }}$ ed.

Pastoret, P. P.; Babiuk, L. A.; Misra, V. and Riebel, P. (1980): Reactivation of temperature sensitive and non Temperature sensitive IBR vaccine with dexamethasone. Infect. Immun. 29: 483 - 488.

Payment, P. and Trudel, M. (1993): Methods and Techniques in virology. Marcel Dekker, New York.

Reed, L. J. and Muench, A. (1938): A simple method for estimating fifty percent end points. Amer. J. Hyg., 27: 493 497.

Seal, B. S.; Martinez, J. D.; Hall, M. R. and Jeor, S. C. (1988): Occurrence of bovine herpes virus -1 DNA in nucleosomes and chromatin of bovine herpes virus -1infected cells: identification of a virion- associated protein in chromatin of infected cells. Arch. Virol., 99 (3-4): 221 236.

Shehab,G.J.; Rawhia, M.A.O.; Hosny, J.A. and Aly, N.M. (1996): An out break of pneumoenteritis in calves caused by IBR and Rota viruses in Egypt. Virological and Immunopathological Aspects. Egyp. J. Comp. Pathol. Clinpathol., 9 (2): $15-37$.

Straub, O.C. (1986): Suitability of immune diffusion for determining humeral antibodies against BHV-I. Berliner Und Munchener Tierartliche Wochenschrift, 99 (12): 424 427.

Winkler, M. T. C.; Doster, A. and Jones, C. (1999): Bovine herpes virus 1 can infect $\mathrm{CD} 4^{+} \mathrm{T}$ Lymphocytes and induce programmed cell death during acute infection of cattle. J. Virol., 73 (10): 8657 - 8668.



